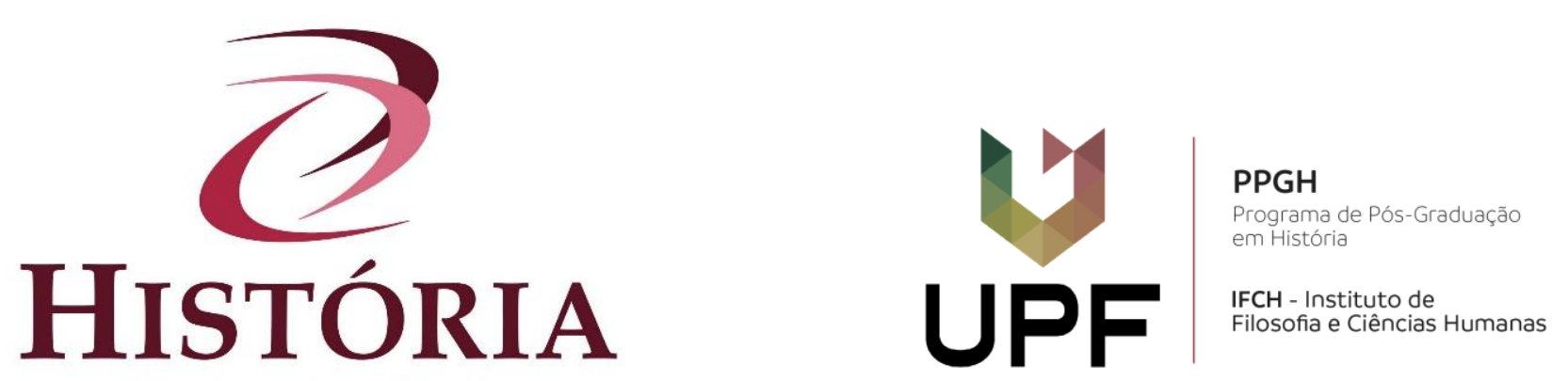

debates e tendências

\title{
Os Escritos de Raymundo José da Cunha Mattos e a Temática Indígena no IHGB
}

The Writings of Raymundo José da Cunha Mattos and the Indigenous Theme at IHGB

\section{Los Escritos de Raymundo José da Cunha Mattos y la Temática Indígena en el IHGB}

\author{
Martha Victor Vieira ${ }^{\mathrm{i}}$
}

\begin{abstract}
Resumo: Este artigo pretende analisar alguns escritos de Raymundo José da Cunha Mattos publicados na Revista do Instituto Histórico e Geográfico Brasileiro (RIHGB), enfocando sua concepção de história e seu interesse em investigar e narrar à temática indígena. Parte-se do pressuposto que, sendo a disciplina de história uma importante aliada dos Estados nacionais nesta época, o incentivo aos estudos sobre os povos indígenas era bastante útil porque ajudaria a assimilá-los, consolidaria a soberania territorial interna, afirmaria a nacionalidade brasileira e apontaria alternativas para a carência de mão de obra no país.
\end{abstract}

Palavras-chaves: Cunha Mattos. Indígenas. Escrita da História.

\begin{abstract}
This article intends to analyze some writings of Raymundo José da Cunha Mattos published in the Revista do Instituto Histórico e Geográfico Brasileiro (RIHGB), focusing his conception of history and his interest in investigating and narrating the indigenous theme. The assumption is that, how discipline of history was an important ally of national states at this time, the encouragement of studies on indigenous peoples was very useful because it would help assimilate them, consolidate internal territorial sovereignty, would affirm Brazilian nationality and would point out alternatives to the shortage of labor in the country.
\end{abstract}

Keywords: Cunha Mattos. Indigenous. Written History.

Resumen: Este artículo pretende analizar algunos escritos de Raymundo José da Cunha Mattos publicados en la Revista do Instituto Histórico e Geográfico Brasileiro (RIHGB), enfocando su concepción de historia y su interés en investigar y narrar a la temática indígena. Se parte del supuesto de que, siendo la disciplina de historia una importante aliada de los Estados nacionales en esta época, el incentivo a los estudios sobre los pueblos indígenas era bastante útil porque ayudaría a asimilarlos, consolidaría 
la soberanía territorial interna, afirmaría la nacionalidad brasileña y señalaría alternativas a la escasez de mano de obra en el país.

Palabras clave: Cunha Mattos. Indígenas. Escritura de la Historia.

A fundação do Instituto Histórico e Geográfico Brasileiro (IHGB) em 21 de outubro de 1838 e o início da publicação da Revista no ano seguinte marcam uma época áurea da história enquanto disciplina no Brasil. O trabalho de coleta documental e de crítica realizado pelos membros do Instituto demonstra o apreço desses letrados oitocentistas pela história da pátria que pretendiam construir. Não à toa, o IHGB foi criado por iniciativa dos membros da Sociedade Auxiliadora da Indústria Nacional (SAIN), pois conhecer os acontecimentos pregressos do país era uma forma de contribuir para pensar questões e soluções para as demandas práticas que visavam o progresso do Brasil. Para os fundadores do Instituto, Januário da Cunha Barboza e Raymundo José da Cunha Mattos as letras eram de "uma absoluta e indispensável necessidade, principalmente aquelas que, versando sobre a história e geografia do paiz, devem prestar grandes auxílios á pública administração” (CUNHA, 1908, p. 6-8).

No século XIX, as disciplinas de história e geografia do Brasil eram as maiores aliadas do Estado Imperial porque esses conhecimentos contribuiriam para a consolidação da soberania territorial. Sem historiadores para narrar os fatos do passado, atribuindo-lhes um sentido que se relacionassem ao presente, não era possível forjar uma nação (HOBSBAWM, 2000,), estimular sentimentos identitários e mobilizar as pessoas para ação. Sem expedições geográficas para pensar, cartografar e dar visibilidade aos limites tornar-se-ia difícil estabelecer e defender as fronteiras territoriais do país (MAGNOLI, 2003,). Eram essas ideias que norteavam as ações dos fundadores do IHGB que, se inspirando no Instituto Histórico de Paris, resolveram criar uma associação literária que tinha como finalidade narrar à história e geografia do Brasil, promover o ensino dessas áreas disciplinares e corrigir os dados equivocados que constavam em impressos nacionais e estrangeiros.

Nas primeiras reuniões e publicações do Instituto era consenso que se deveria estudar os indígenas brasileiros. De acordo com Manoel Salgado Guimarães, os indígenas foram "um dos temas centrais da Revista do IHGB ao longo de todas as duas décadas posteriores a sua fundação" (GUIMARÃES, 2006, p. 82). Inclusive, o primeiro texto publicado na Revista intitula-se História dos Índios Cavalleiros ou da Nação Guaycuru, assinado por Francisco Rodrigues do Prado. Já na sessão de 4 de fevereiro de 
1839, dos seis pontos destacados pelo cônego Januário da Cunha Barbosa para serem discutidos pelos membros, quatro referiam-se a essa temática. Os assuntos propostos pelo cônego referiam-se às sugestões de estudo sobre a extinção dos indígenas do litoral, a fim de entender se isso tinha relação com expulsão dos jesuítas; a história dos indígenas no período pré-colombiano, incluindo costumes, língua e origem; melhor meio de civilizar os indígenas do sertão e verificar se presença de africanos atrapalhava civilização dos indígenas e o impacto dos usos dos escravos para a lavoura (ATA, 1908 p. 47-48).

Essas discussões iniciais, que parecem representar as primeiras preocupações dos sócios do IHGB, podem ser encontradas em outros textos publicados na Revista, chama-nos atenção, contudo, os escritos de Raymundo José da Cunha Mattos, porque apesar de ter participado de tão poucas reuniões antes de falecer em fevereiro de 1839, a sua Dissertação acerca do sistema de escrever a história antiga e moderna do Império do Brasil e a Chorographia Histórica da Provincia de Goyas, publicadas postumamente, revelam a sintonia das suas ideias com os programas do Instituto. Isso, evidentemente, não é casual, visto que, como aponta Manoel Salgado, a base intelectual dos fundadores do IHGB são as ideias iluministas, embora essas sejam reformuladas pelas demandas do Estado/nação e pela emergência da história como disciplina científica no século XIX, (SALGADO,2006).

\section{A trajetória de Cunha Mattos}

Raymundo José da Cunha Mattos nasceu em Portugal, na cidade de Faro, no dia 02 de novembro de 1776. Aos quatorze anos de idade ingressou no serviço militar e participou da campanha contra a França na Península Ibéri0ca. Formou-se na Escola Regimental de Faro no curso de matemática pura aplicada à artilharia. Sua ascensão na carreira militar ocorreu de forma célere, na medida em que exercia com competência as funções ocupadas e se entrosava nas relações clientelares vigentes. Nomeado, em 1797, como comandante da Fortaleza de São Sebastião da Barra, na Ilha de São Tomé e Príncipe, na África, residiu nesse país por dezenove anos. Em 1812, foi condecorado com o Hábito da Ordem de São Bento de Avis e, em 1813, foi promovido a tenentecoronel. Esteve de passagem no Rio de Janeiro, em 1814, retornando para a Ilha de São Tomé no cargo de governador interino (SOARES, 1931; MACHADO, 2001). 
A fixação desse militar português no Reino Unido do Brasil ocorreu por volta de 1817, quando combateu a Insurreição Pernambucana. Em 1818, foi promovido a coronel e assumiu o comando de artilharia em Pernambuco, tendo permanecido nessa província por dois anos. Foi vice-inspetor do Arsenal Real do Exército na Corte, em 1819 (SOARES, 1931). Nomeado para ser o governador das armas da província de Goiás, partiu do Rio de Janeiro, com uma pequena comitiva, em direção ao Brasil central, chegando em 15 de junho de 1823 na Cidade de Goiás.

Na província de Goiás, sua missão era resguardar militarmente as fronteiras do norte goiano, evitando a invasão de supostas tropas portuguesas, que estariam assentadas no Maranhão, Pará e Piauí. A ameaça de uma possível recolonização portuguesa ainda assombrava as elites brasileiras neste período. Em 1825, Cunha Mattos ascendeu ao posto de brigadeiro efetivo do Exército. No ano seguinte, deixou o cargo de governador das armas e retornou para Corte, porque foi eleito como deputado para a Assembleia Geral pelos cidadãos goianos (VIEIRA, 2012).

Como representante político de Goiás, atuou em duas legislaturas consecutivas (1826-1829; 1830-1833). Sob o comando do marquês de Barbacena, participou, por um curto período, da Campanha da Cisplatina (1825-1828). Em 1829, recebeu a comenda de Oficial da Ordem Imperial do Cruzeiro. Alguns meses após a Abdicação de D. Pedro I, licenciou-se das funções políticas e do cargo de inspetor do Arsenal de Guerra da Corte, para realizar uma viagem com sua família a Portugal, retornando apenas em 1833. Ao retornar, Cunha Mattos dedicou-se as atividades letradas e administrativas. Quando morreu na capital do Império, em 23 de fevereiro de 1839, já detinha a patente de marechal de campo do Exército. Deixou a esposa, Maria Venância de Fontes Pereira de Mello, e um casal de filhos (RODRIGUES, 2008).

Nos seus escritos, Cunha Mattos demonstra ser um sujeito de postura pragmática e opiniões arraigadas. No seu leito de morte teria exigido que não fosse enterrado sem fazer uma autópsia do seu corpo, porque, simplesmente, discordava do diagnóstico do seu médico (RODRIGUES, 2008). Ainda no leito de morte, teria pedido a Januário da Cunha Barboza que lesse na sessão do Instituto uma carta sua, na qual dizia lamentar o fato de não ter dado uma contribuição maior para o Instituto e para a Sociedade Auxiliadora da Indústria Nacional (ATA, 1908 p. 49-50).

Por meio da análise das narrativas construídas por Cunha Mattos, se pode inferir o seu comprometimento e fidelidade com o Império pelo qual lutou nas frentes de batalha em três continentes, Europa, África e América. Primeiro, serviu defendendo 
os interesses de Portugal, sua pátria de nascimento. Depois serviu ao Brasil, pátria por adoção e domicílio, cuja independência aderiu após perceber que não seria possível manter os laços de união entre os dois reinos (MATTOS, 1822). Seus textos demonstram essa sua identidade política híbrida.

O que chama atenção em Cunha Mattos é que o seu interesse pelas questões militares conviveu com a sua habilidade letrada e político-administrativa, o que demonstrou como deputado, primeiro secretário da SAIN e vice-presidente do IHGB. No elogio histórico feito sobre a sua morte na Revista do IHGB ressalta-se a sua trajetória, que começou como reles soldado, alcançou altas patentes e obteve reputação literária. Mesmo quando estava em campanha militar, ele aproveitava seu tempo livre para escrever memórias históricas, analíticas e estatísticas dos lugares por onde passava. Sua intenção era servir ao Estado, "quer pelos serviços militares, quer pelos literários" (BELLEGARDE, 1839, p. 221-224). O propalado apreço pelas letras, associada a sua reconhecida competência militar, fez com que Americano do Brasil o definisse como “illustre philosopho militar" (BRASIL, 1927, p. 183).

O interesse pela geografia brasileira, seção a qual pertencia no Instituto, está evidente nas páginas do seu Itinerário do Rio de Janeiro ao Pará e Maranhão pelas Províncias de Minas Gerais e Goiaz, escrito entre 1823 e 1826, que consiste num relato meticuloso do percurso feito, contendo informações sobre o clima, rios, serras e condições dos caminhos. Com base nos dados coletados, Cunha Mattos chegou a elaborar um mapa sobre a Província de Goiás. Seu intuito, porém, não era apenas fornecer informações geográficas, mas, igualmente, fornecer instruções e sugerir precauções e providências que deveriam tomar os outros viajantes que pretendessem se enveredar pelo sertão (MATTOS, 1836).

A maior parte do Itinerário versou sobre os arraiais goianos, os quais ele visitou com o intuito de realizar a revista nas tropas. Sua narrativa, contudo, não se restringia às questões militares, pois englobou densas descrições sobre os costumes sertanejos e a situação socioeconômica existente na província. Mais do que descritivo, o Itinerário, na definição de seu narrador, pretendia ser científico. Pode-se dizer também que era propositivo, na medida em que se referia às potencialidades a serem exploradas na região. No mesmo padrão estilístico foi redigida a Chorographia Histórica da Província de Goiaz, que contém uma análise arguta das carências comerciais e agrícolas do território goiano. Essa obra, cujo manuscrito foi oferecido ao IHGB pela viúva Maria 
Venância de Fontes Pereira de Mello, foi escrita em 1824, mas sofreu alguns acréscimos antes de ser publicada na Revista em 1874 e 1875 (MATTOS, 1875).

A Chorographia Histórica de Goiaz, tal como o Itinerário, consiste em uma narrativa sobre as informações históricas, geográficas e administrativas da província. Nela se descreve os arraiais, as aldeias, os moradores, os indígenas, os rios, as habitações, as montanhas, a produção vegetal, animal e mineral. Mas traz também relatos dos custos dos povoados e aldeias para o Estado, bem como destaca o potencial econômico do comércio, da navegação e da agricultura. Uma marca dessa obra é, recorrentemente, se enfatizar a decadência econômica da província. Para ele, a "decadência das lavras" teria como causa primeira a "preguiça dos homens", que abandonaram as minas (MATTOS, 1874, p. 296).

Devido às mudanças ocorridas no Império português e brasileiro, Cunha Mattos teve que reorientar suas posições políticas, contudo, independente do lugar e do momento em que tenha manifestado suas ideias, a sua linguagem possuía uma particularidade: o tom crítico, incisivo e propositivo. Como um militar formado na tradição do iluminismo português, ele acreditava que a ciência devia ter uma utilidade social e contribuir para o progresso. Essa visão pragmática ele sustentou nos textos publicados na Revista do IHGB. O objetivo de Cunha Mattos era escrever "sem perder de vista o interesse de ser útil ao Estado" (MATTOS, 1874, p. 219). Era assim que esse oficial letrado concebia a escrita da história.

\section{O caráter da escrita histórica}

No início da sua fundação, o IHGB promoveu um produtivo debate sobre a melhor forma de narrar à história do Brasil. Desse debate resultou o concurso cuja monografia premiada foi de Karl Friedrich Phillipp von Martius, intitulada Como se deve escrever a história do Brasil, publicada em 1844. Embora o trabalho de Martius seja o mais lembrado, outros sócios do Instituto abordaram essa temática, incluindo Cunha Mattos que manifestou sobre sua concepção de história na Dissertação acerca do sistema de escrever a história antiga e moderna do Império do Brasil, lida na sessão do Instituto de 15 de dezembro de 1838, mas divulgada na Revista do IHGB somente em 1863. 
Nessa Dissertação ele afirmou que a "história é a sciência de narrar ou descrever os acontecimentos presentes e os passados", com a finalidade de melhorar a sociedade. Nas suas palavras: o "fim principal da história política e civil, é encaminhar os homens á prática das virtudes e o aborrecimento dos vícios para que d'ahi resulte o bem estar das sociedades". As fontes para se escrever a história poderiam ser resquícios da cultura material e documentos oficiais, cuja autenticidade deveria ser investigada (MATTOS, 1863, p. 137-138). Pensamento semelhante era manifestado por Januário da Cunha Barboza, segundo o qual a história poderia fornecer "lições" preciosas para os homens no presente, ensinando os cidadãos brasileiros os seus deveres (BARBOZA,1908 p. 9). Nestes termos, baseados na tradição do "iluminismo português, marcadamente católico e conservador", os pais fundadores do IHGB, entendiam que as lições da história contribuiria para elaborar um projeto para o futuro do país (GUIMARÃES, 1988, p. 14).

A concepção de que a história deveria ter uma função pragmática foi colocada em outros trabalhos que escreveu. Na introdução da Chorographia Histórica da Província de Goyas, Cunha Mattos afirma ser o seu dever "como empregado público" que o levou a escrever essa narrativa, a qual era dedicada a D. Pedro I, a fim de que ele como "pai de todos os goianos" pudesse aplicar "remédios aos males" existentes na província (MATTOS, 1874, p. 214).

Escrever a história de Goiás, para Cunha Mattos, foi uma tarefa difícil por estar no centro do Brasil, onde lhe faltavam recursos científicos, roteiros e memórias com informações confiáveis que pudesse consultar. Os poucos escritos estrangeiros que circulavam sobre Goiás eram, geralmente, falhos, especialmente, por não terem interesse em melhorar o comércio, a agricultura, e propor "meios de povoar e civilisar a província”. Algumas memórias de funcionários que escreveram sobre temas que interessavam ao desenvolvimento da região ainda eram desconhecidas do público. Muitas das informações da sua Chorographia teriam sido retiradas da Chorographia Brasílica do padre Manuel Aires de Casal, publicada em 1817. Outra fonte de informação foi o texto Memória sobre o descobrimento, governo, população, e cousas mais notáveis da Capitania de Goyas de Luiz Antônio da Silva e Souza, datada de 1812. Ademais, descrevia situações que presenciara pessoalmente e ouvira dos habitantes dos lugares por onde passou (MATTOS, 1874, p. 215-217).

Na sua Dissertação acerca do sistema de escrever a história antiga e moderna do Império do Brasil, Cunha Mattos também reclamou a ausência de fontes, afirmando que, em relação à escrita da história "philosophica do povo do Brasil", era preciso fazer 
uma análise rigorosa ao "imenso fardel de escriptos inexactos, insulsos, indigestos, absurdos e fabulosos anteriores ao anno 1822 em que unicamente se imprimia em Portugal e raríssimas vezes no Brasil" (MATTOS,1863, p. 122-123). Nesse aspecto, Cunha Mattos chama atenção para a importância de se realizar a crítica documental e para o fato de haverem muitos estrangeiros que escreveram inverdades sobre a história do Brasil, que depreciavam o povo brasileiro. O próprio Robert Southey teria chamado os brasileiros de "supersticiosos e idólatras".

A ênfase na ausência de fontes primárias, na interpretação de Manoel Salgado Guimarães, relaciona-se ao fato da escrita desses fundadores do IHGB, apesar de conter indícios das ideias iluministas, possuir, igualmente, traços de uma "visão moderna da história", que pressupõe certos critérios de cientificidade (GUIMARÃES,1988, p. 1418). Um desses critérios era adquirir fontes e realizar a crítica dos "monumentos", a fim de evitar que se produzisse "ficções em vez de realidades" (MATTOS, 1863, p. 138139). Seguindo essa linha de raciocínio, pode-se inferir que é com base nesse crivo científico que, ao comentar os erros históricos que constavam nos escritos estrangeiros, Cunha Mattos reivindica para o IHGB o discurso autorizado para escrever a história do Brasil.

Há ainda nesse argumento um dual brio patriótico, ao chamar a responsabilidade de escrever a história do Brasil para os luso-brasileiros. Isso pode ser observado na ressalva feita de que tanto brasileiros quanto portugueses escreveram textos interessantes sobre o Brasil. A não publicação das viagens feitas por "naturalistas nacionais" devia-se a falta de apoio financeiro e a censura dos livros, pois Portugal, até 1808, restringia as publicações que falassem sobre as províncias brasileiras por temor das invasões de outros países (MATTOS, 1863).

Na visão desse escritor, "a censura lançou pêas aos talentos dos brasileiros e portugueses", porque antes de 1580, ninguém poderia criticar a administração. Não se podia escrever livremente nem na colônia, nem na metrópole. Ninguém se arriscava a dizer "a verdade aos reis". O historiador era condenado ao silêncio, excetuando alguns como o padre Antônio Vieira. E isso era um problema porque a história só pode ser escrita quando os historiadores possuíssem uma "inteira e sensata liberdade". Pelo fato de a liberdade de escrever ter-se tornado possível apenas a partir de 1823, não havia bons escritos nacionais e isto tornava "impossível” escrever uma história geral do Brasil (MATTOS, 1863, p. 127-129). 
A menção a 1808 é devido à criação da Imprensa Régia nesta data. Em relação à superação da censura em 1823, possivelmente, deve-se a aprovação nesse ano da lei sobre a liberdade de imprensa. Contudo, essa lei, além de regulamentar as atividades da imprensa, também restringia o conteúdo que circulava nos periódicos, e estabelecia punições com multas, penas de prisão e degredo. O decreto de 20 de setembro de 1830 e o Código Criminal de 16 de dezembro de 1830 reforçaram a censura à imprensa. A justificativa dessas restrições, durante o Primeiro Reinado e início das Regências, era coibir os abusos cometidos pelos periódicos (NUNES, 2010).

Apesar de ter sido deputado nesse período, Cunha Mattos se silencia sobre esses tropeços da imprensa imperial, porém, precisa-se ressalvar que a sua Dissertação enfoca as obras históricas e destaca o aumento das tipografias, que foram ampliadas a partir da Independência. As leis sobre imprensa tinham como alvo, especialmente, as publicações de cunho político e as manifestações orais que criticassem o governo monárquico.

O zelo científico que fazia Cunha Mattos lamentar a falta de fontes, em parte por causa da censura à imprensa na época colonial, e a necessidade de realizar a crítica documental são reforçados devido ao caráter da sua proposta de escrita e divisão cronológica da história do Brasil. Nessa proposta cronológica, a primeira época a ser descrita era a história dos indígenas brasileiros; e era justamente na elaboração dessa narrativa que residiriam às maiores carências de informações e os maiores equívocos nos impressos estrangeiros.

\section{A história dos indígenas: a aplicação de um modelo de escrita}

O conteúdo da Dissertação acerca do sistema de escrever a história antiga e moderna do Império do Brasil evidencia que há certo consenso no IHGB em torno da necessidade de se investigar e narrar à história dos indígenas brasileiros. Por essa razão, não é de se surpreender que a Dissertação de Cunha Mattos, seguindo uma sugestão do cônego Januário da Cunha Barboza, defendesse que a história do Brasil deveria ser dividida em três épocas: a primeira trataria dos "aborígenes"; a segunda dos "descobrimentos" portugueses e da administração colonial; e a terceira a partir da data em que "o povo brasileiro se constituiu soberano e independente, e abraçou um systema de governo imperial, hereditário, constitucional e representativo" (MATTOS, 1863, p.129). 
Na medida em que expõe sua proposta de escrita da história do Brasil, Cunha Mattos faz uma interpretação do passado colonial e da história do contato. Segundo ele, os portugueses desde que estabeleceram as primeiras feitorias haviam notado que os indígenas eram de nações diferentes e falavam línguas diversas. Mas os primeiros colonizadores, principalmente os vicentinos, estavam mais preocupados em realizar expedições "guerreiras e mercantis" do que filosóficas e filantrópicas. Por isso, não coletaram informações sobre os povos indígenas do sertão. Foi somente com a vinda dos jesuítas, em 1549, que "se deu principio ao exame da história de uma raça, que ainda se achava mui distante da aurora da civilização" (MATTOS, 1863, p. 131).

Os jesuítas teriam produzidos dicionários da língua guarani e tupi, que era ensinada nos seus colégios. A essa língua deram o nome de "geral" por que era compreendida e falada por quase todos os índios. A língua portuguesa praticamente não era usada nas aldeias jesuíticas, sobretudo nos sertões do Brasil. Esses missionários, ao proibirem a entrada dos portugueses nas suas missões e utilizarem apenas a língua geral despertaram "grandes e bem fundadas suspeitas" sobre estarem tentando construir na colônia uma nação teocrática. As suspeitas foram fortalecidas quando no sul do país os espanhóis e portugueses se depararam com um “exército" de indígenas liderados pelos missionários. Ao fazerem os dicionários tupi-guarani, os jesuítas, porém, não aprofundaram nos estudos dessa língua, nem na história das emigrações. Por isso a etnografia da população indígena americana ainda era desconhecida, bem como suas línguas eram de origens incertas (MATTOS, 1863, p. 131-132).

Em virtude da dificuldade de encontrar informações e de se comunicar com os aborígenes, para Cunha Mattos, escrever essa história era uma empresa difícil. Os próprios indígenas não sabiam dar informações sobre o lugar de onde vieram, pois em suas narrativas havia muita "fábula" (MATTOS, 1863, p. 129). Diante do desconhecimento da história dos indígenas e das histórias particulares das províncias, Cunha Mattos reiterava sua posição de que não havia dados suficientes para se escrever uma história geral do Brasil. No tocante a esta argumentação, Manoel Salgado Guimarães aponta, com muita propriedade, que Cunha Mattos efetivamente revela sua preocupação com o caráter científico da moderna escrita da história, que seria tanto mais confiável quanto mais se amparasse em fontes consideradas fidedignas (GUIMARÃES, 2007).

Cunha Mattos lamentava o fato dos governos português e brasileiro não terem encarregados alguns "sábios" de realizar estudos arqueológicos e etnográficos, pois isso 
fez com que circulasse relatos duvidosos. Na sua visão, muitos naturalistas estrangeiros que viajaram pelo Brasil e escreveram sobre os aborígenes, não possuíam conhecimento e, por isso, “[...] alguns d'elles improvisaram, e até se inculcaram conhecedores de tribus, que nunca viram, e de idiomas e dialetos, que nunca examinaram [...]" (MATTOS, 1863, p. 136). Além da arqueologia e da etnografia, a ciência lingüística era outra esperança de recuperar a origem dos indígenas brasileiros, a fim de verificar se eram autóctones ou vieram de terras distantes.

À importância do conhecimento da língua indígena não serviria apenas para se conhecer a sua história, mas também para facilitar o contato com esses povos. Os índios "mansos e civilizados", que eram usados como intérpretes, na maior parte das vezes, já não dominavam mais a língua, sobretudo, em lugares onde havia uma diversidade de etnias como no Brasil central (MATTOS, 1863, p. 136). Isso era um problema para as autoridades que tinham que negociar com os indígenas, bem como para à assimilação dos mesmos.

$\mathrm{O}$ contato $\mathrm{e}$ as dificuldades que teve com os povos indígenas quando foi governador das armas em Goiás parece ter sido um primeiro estímulo para ele começar a refletir sobre essa questão (GUIMARÃES, 2007, p. 114), haja vista que a temática dos indígenas já estava colocada na Chorographia Histórica da Província de Goyas. Nessa obra, cujo traçado geral foi feito em 1824 quando Cunha Mattos deixou o cargo de governador e retornou ao Rio de Janeiro, no tópico intitulado "História Geral da Província", ele admitia ser praticamente "impossível penetrar na tenebrosa noite dos tempos" para encontrar a origem das nações que povoavam o país na época da “descoberta” (MATTOS, 1875, p.79).

Entretanto, nesta parte da Chrorographia, ele ensaia alguns comentários sobre essa origem. Em sua opinião, os indígenas americanos seriam descendentes dos Mongólicos ou Togures e teriam chegado ao continente pelo Estreito de Bering. Os aborígenes brasileiros seriam descendentes dos "Tártaros da Sibéria ou das ilhas próximas", que se constituíram em nações distintas, sendo os mais poderosos os Tupinambás. Foram esses Tupinambás que povoaram a parte oriental de Goiás, onde tomaram os nomes de "Chavantes, Cherentes, Gês, Acroás e outros que se subdividiram". A base do idioma desses povos seria a mesma. Contudo, "Carajás, Carajais, Xambiuás, Javahés, Tapirapés, e Coritis" pareciam ser de tronco diferente, por causa do idioma usado (MATTOS, 1875, p. 77). 
Contrariando as crônicas coloniais que tanto criticava, Cunha Mattos afirmava que se enganavam os escritos que propalaram a inexistência de governantes entre os indígenas brasileiros, porque esses povos tinham um "governo militar", que era exercido pelo "chefe da tribu". Aponta ainda que, por causa das constantes guerras que lhes eram feitas, trabalhos pesados e doenças adquiridas, à tendência eram que os povos indígenas desaparecessem, pois muitas aldeias já haviam se extinguido (MATTOS, 1875, p. 79).

Teria sido a expedição de Bartolomeu Bueno da Silva que realizou o primeiro contato com os índios Goyazes em 1670 e noticiou em São Paulo a possibilidade de existência de metais preciosos nessa região. Posteriormente, seu filho Bartolomeu Bueno, o moço, veio em uma nova bandeira em 1722 para "descobrir e conquistar". Não tendo êxito nessa bandeira, retornou em 1726. Nesta data começou a colonização de Goiás, que foi próspera enquanto a mineração era rentável. Entretanto, devido à queda na produção de minério, a falta de braços escravos e as hostilidades dos indígenas, a província entrou em processo de decadência (MATTOS, 1875, p. 80-87).

Pela leitura da Chorographia Histórica da Província de Goyas pode-se observar uma semelhança do tópico "História Geral da Província" com o modelo proposto na Dissertação acerca do sistema de escrever a história antiga e moderna do Império do Brasil. Infere-se isso porque esta parte aplica o modelo de escrita proposto por Cunha Mattos, na medida em que primeiro descreve-se a história dos aborígenes, depois se narra o descobrimento de Goiás e as administrações dos capitães-generais e, por fim, chega-se ao início da fase moderna, que abrangeria os acontecimentos a partir de 1822. Essa narrativa termina, porém, com a ascensão de Caetano Maria Lopes Gama ao governo goiano em 1824.

Não pretendemos, neste momento, realizar uma análise hermenêutica, mas nesta parte "moderna", curiosamente, a atuação de Cunha Mattos no governo das armas de Goiás é descrita na terceira pessoa, conforme se nota nesta citação: "As repetidas queixas bem ou mal fundadas de alguns moradores da cidade, ou mesmo fora d'ella contra o governo provisório, acelerou a nomeação de Raymundo José da Cunha Mattos para o emprego de governador das armas" (MATTOS, 1875, p. 91). Em outro fragmento: "O governador das armas que tinha hido passar a revista nas tropas foi avisado d'esses acontecimentos pela junta de governo". Isso indica que, provavelmente, alguém editou ou realizou algumas intervenções nesta versão póstuma que foi publicada em 1874 e 1875 na Revista do IHGB. 
Embora haja algumas passagens que causem estranhamento no final desta parte que se intitula "História Geral da Província", o texto, no geral, traz o estilo retórico de Cunha Mattos, que, geralmente, iniciava sua argumentação usando de certa modéstia, mas sempre incisivo. Pode-se notar isso na introdução da Chorographia quando ele afirma que pretendia elaborar "uma obra instrutiva", mas como era "falto de talentos" conseguira apenas apresentar "algumas memórias mui superficiais" (MATTOS, 1974, p. 215). Igualmente, no tópico "História Geral da Província", em que narra à história dos indígenas goianos, ao reiterar o problema da falta de fontes, desabafa: "vou tentar a árdua empreza de realizar este intricado trabalho, apalpando em uma parte, cahindo em outra e errando talvez em todas, porque em tudo há confusão [...]" (MATTOS, 1875, p. 76).

A "confusão" devia-se a ausência de documentos para escrever a história dos indígenas, por isso, Cunha Mattos insistia que os estudos arqueológicos, etnográficos e línguisticos coadjuvariam para o conhecimento desses povos. Diante do consenso sobre a importância da temática indígena, o IHGB criou, oficialmente, em 1847 uma seção de etnografia e arqueologia (TURIN, 2006). Esse conhecimento deveria servir para integrar os povos originais do território, promover a catequização e levar a civilização para os sertões do país. Nesse sentido, as contribuições históricas de Cunha Mattos tiveram continuidade e foram aprofundadas pelos estudos de outros sócios do IHGB.

\section{Considerações finais}

O interesse de Cunha Mattos em construir a história dos indígenas é notório na Dissertação acerca do sistema de escrever a história antiga e moderna do Império do Brasil, bem como no pequeno ensaio que, provavelmente, ele agregou posteriormente ao texto original da Chorographia Histórica da Província de Goyas. Aliás, a temática indígena está presente nos textos de vários letrados brasileiros, a partir de 1830, sendo esta uma tendência de escrita do movimento literário romântico. Nesse empenho em representar os indígenas, seja pelos românticos ou membros do IHGB, se podem vislumbrar pelo menos cinco objetivos bastante pragmáticos, que são apontados no referenciado texto de Manoel Salgado Guimarães (1988, p. 21-21): a busca de um símbolo representativo da nacionalidade; o debate sobre a transição da mão de obra escrava para e livre; a demanda territorial, devido à expansão da agropecuária; a promoção da integração dos indígenas, para submetê-los ao poder público, e razões 
“político-estratégicas" para assegurar a soberania do Estado imperial nas regiões fronteiriças.

Podemos acrescentar dois outros aspectos, tomando como referência os escritos de Cunha Mattos. O primeiro é repensar se era produtivo dar continuidade ao modelo português de civilização dos povos originários, que foi feito pela catequese, empreendida, principalmente, pelos jesuítas, e com base na força física. O segundo aspecto é um notório esforço de procurar fontes fidedignas para construir a história do Brasil, a fim de desconstruir as versões coloniais, que foram escritas fora do país e muitas vezes por estrangeiros, reafirmando assim a competência da intelectualidade brasileira e a independência no âmbito cultural e político. Trata-se do que Temístocles Cesar vai compreender como um "objetivo de nacionalizar a cadeia cognitiva que narra os eventos desde o período colonial” (CESAR,2004, p. 14).

Esse trabalho de (des)construção do IHGB, ou nacionalização do saber, é deveras interessante porque os integrantes do Instituto querem evidenciar os equívocos cometidos nos primeiros relatos sobre o Brasil colonial, no que tange à questão indígena, reivindicando para si mesmos o discurso autorizado para realizar essa narrativa. Entretanto, essa revisão histórica, nitidamente, foi limitada/interditada pelo local da fala dos atores (CERTEAU, 1982), que estavam atrelados ao Estado imperial e possuíam uma concepção de história híbrida, que tentava conciliar perspectivas distintas: ser mestra da vida e ser científica, dar lições e construir realidades objetivas e não ficções, criticar a violência contra os indígenas e contar as ações dos homens ilustres, propalar uma perspectiva humanitária e contribuir com a construção do Estado nacional. Não havia consciência possível para se conceber uma história que adotasse, efetivamente, a perspectiva indígena, apenas recentemente isso tem sido efetuado pela nova história indígena e pelos estudos embasados na chamada teoria decolonial (BRIGHENTI, 2016). A cultura historiográfica oitocentista está atrelada a uma concepção da história vista de cima.

Os membros do IHGB, recrutados entre a elite, não cogitavam escrever uma história e uma geografia que atentasse contra os interesses do Estado e dos proprietários de terras. Cunha Mattos, como um oficial letrado, defende que a escrita da história fosse instrutiva ao presente, sugerindo ideias para o desenvolvimento geopolítico e econômico do Brasil. Não à toa, na Chorographia Histórica da Província de Goyas, dedicadas a D. Pedro I, pode-se notar que as informações tanto sobre o passado quanto sobre presente eram descritas, juntamente com as propostas do que podia ser melhorado, a fim de que o 
conteúdo pudesse ser útil ao progresso da pátria. É essa vontade de progresso que fazia com que ele, recorrentemente, ressaltasse a decadência de Goiás. Como diz Joel Serrão, "só tem sentido afirmar que algo decai, após ter postulado previamente, em que consiste subir, ou progredir para dada meta" (SERRÃO,1981, p. 270).

Ao escrever sobre a história de Goiás sua intenção é contribuir para que o Estado tomasse conhecimento e ajudasse a alavancar a economia de Goiás, talvez por isso tenha dedicado o trabalho ao Imperador, na expectativa que lesse e remediasse os "males" da província. No discurso propositivo e etnocêntrico contido nesta obra, os indígenas são, várias vezes, representados como um obstáculo ao desenvolvimento, porque inibiam a navegação e a fixação de moradores na região.

A possível utilidade das informações presentes nesta Chrographia goiana para o governo imperial indica que ela não foi escrita apenas por apreço ao conhecimento, pois, dentro da lógica clientelista vigente, o trabalho letrado pode ter sido recompensado com préstimos pessoais. Mas, não se pode menosprezar o fato de que Cunha Mattos era um amante das letras e tinha uma formação fundamentada na ilustração, cuja filosofia acreditava que o conhecimento poderia servir para promover o bem estar social, como ele aponta na Dissertação acerca do sistema de escrever a história antiga e moderna do Império do Brasil.

Foi esse tipo de pensamento que mobilizou os estadistas portugueses, a partir do final do século XVIII, a incentivarem os estudos e a divulgação de pesquisas técnicocientíficas que proporcionassem uma melhoria da gestão do campo cultural, da agricultura, da mineralogia e do comércio. As informações coletadas por esses "homens de ciência" deveriam servir de base para que o Império luso-brasileiro pudesse ser reformado e mais bem administrado (KURY, 2004). Atuando como militar e homem de ciência a serviço do Estado imperial, Cunha Mattos apontou em várias manifestações discursivas os caminhos a serem seguidos para que o progresso do Brasil oitocentista se efetivasse. O conhecimento histórico e etnográfico dos indígenas iria contribuir para esse projeto porque poderia, no limite, justificar a conquista e exploração do território em prol de uma causa dita civilizatória.

Tanto a Chorographia goiana quanto a Dissertação, escritas por Cunha Mattos e publicadas na Revista do IHGB, demonstram a retórica afiada desse oficial letrado, que não se furtou de disputar com outros sócios sobre como se deveria escrever à história do Brasil. Afinal, um indivíduo não pode esquivar-se de si mesmo, das suas redes de sociabilidade e da cultura histórica na qual está inserido. As proposições autoritárias, a 
reverência ao Governo monárquico e a linguagem lógica e acrimoniosa de Cunha Mattos são produtos da sua trajetória intelectual e militar, das experiências e expectativas de um agente político que não se contentou em assistir placidamente a passagem do trem da história, sem tentar interferir nos rumos dessa instável viagem.

\section{Referências}

ATA da Sessão do Instituto Histórico e Geográfico Brasileiro em 04 de fevereiro de 1839. In. Revista do Instituto Histórico, Geográfico e Etnográfico do Brasil. Rio de Janeiro: Imprensa Nacional, tomo I, p.47-48, 1908.

ATA da Sessão do Instituto Histórico e Geográfico Brasileiro em 02 de março de 1839. In. Revista do Instituto Histórico, Geográfico e Etnográfico do Brasil. Rio de Janeiro: Imprensa Nacional, tomo I, p.49-50, 1908.

BARBOSA, Januário da Cunha. Discurso. In. Revista do Instituto Histórico e Geográfico do Brazil. I. Rio de Janeiro: Imprensa nacional, $3 .^{\circ}$ ed, $1 .^{\circ}$ Trimestre, Tomo I, N. 1, p. 9-17, 1908.

BELLEGARDE, Pedro d Alcantara. Elogio histórico do fallecido vice-presidente, o Marechal Raymundo José da Cunha Mattos. In. Revista do Instituto Histórico, Geográfico Brasileiro. Tomo I, p. 221-226, 1839.

BRASIL, Antônio Americano. Cunha Mattos em Goiás (1823-1826). Revista do Instituto Histórico, Geográfico Brasileiro, Rio de Janeiro, v. 150, Tomo 96, p. 177-251, 1927.

BRIGHENTI, C.A; WITTMANN, L.T; SOUZA, F.F; Colonialidade e decolonialidade no ensino da história e cultura indígena. In.; de. Protagonismo indígena na história. Tubarão-SC: Copiart; [Erechim, RS]: UFFS, 2016. p. 231-285. (Educação para as relações étnico-raciais, $\quad$ v. 4). Disponível em: $<$ https://ayalaboratorio.files.wordpress.com/2017/07/vol4-protagonismo-indc3adgenana-histc3b3ria.pdf $>$. Acesso em: 23 mai 2018.

CERTEAU, Michel. A operação historiográfica. In. A escrita da história. Rio de Janeiro: Forense Universitária, 1982. p. 56-108.

CEZAR, Temístocles. Lição sobre a escrita da História. Historiografia e nação no Brasil do século XIX, Diálogos. Maringá, (8), p. 11-29, 2004.

GUIMARÃES, Manoel Luiz Salgado. Nação e civilização nos trópicos: o Instituto Histórico e Geográfico Brasileiro e o projeto de uma história nacional. In. Revista Estudos Históricos, Rio de Janeiro, v. 1, n. 1, p. 5-27, jan. 1988. 
GUIMARÃES, Manoel. Luiz Salgado. Entre as luzes e o romantismo: tensões da escrita da história do Brasil oitocentista. In. história. Rio de Janeiro: 7Letras, 2006. p. 68-85. (Org.). Estudos sobre a escrita da

GUIMARÃES, M.L.S; CARVALHO, J. M. A disputa pelo passado na cultura histórica oitocentista no Brasil. In. (Org.). Nação e cidadania no Império: novos horizontes. Rio de Janeiro: Civilização Brasileira, 2007. p. 93-122.

KURY, Lorelai. Homens de ciência no Brasil: impérios coloniais e circulação de informações (1780-1810). In. Revista de História, Ciências, Saúde - Manguinhos. Rio de janeiro: Fundação Oswaldo Cruz, vol. 11 (Suplemento 1), p. 109-129, 2004.

HOBSBAWM, Eric. "Etnia e nacionalismo na Europa de hoje". In: BALAKRISHNAN, Gopal. Um mapa da Questão Nacional. Rio de Janeiro: Contraponto, 2000. p. 271-282.

MACHADO, Attila A. Cruz. Processo de habilitação à pensão militar da viúva do Marechal de Campo Graduado do Exército Raimundo José da Cunha Matos, Fundador e Vice-presidente do Instituto Histórico e Geográfico Brasileiro desde a sua fundação. In. Revista do Instituto Histórico e Geográfico Brasileiro. Rio de Janeiro: a. 162, n 410, p. 220-221, jan./mar. 2001.

MAGNOLI, Demétrio. O Estado em busca do seu território. In. Terra Brasilis - Revista de História do Pensamento Geográfico no Brasil. Anos III-IV, no 4-5, p. 1-11. Rio de Janeiro, 2003. Disponível em: < file:///C:/Users/Cliente/Downloads/terrabrasilis-343.pdf >. Acesso em: Ag. 2018.

MATTOS, José Raymundo da Cunha. Nova questão política: que vantagens resultarão aos Reinos do Brasil e de Portugal se conservarem huma união sincera, pacífica e leal. Rio de Janeiro: Typographia do Diário, 1822 p. 11.

MATTOS, José Raymundo da Cunha. Chorographia histórica da Província de Goyas. In. Revista do Instituto Histórico, Geográfico e Etnographico do Brasil. Rio de Janeiro: R. I. Garnier Tomo XXXVII (1), p. 213-398, 1874.

MATTOS, José Raymundo da Cunha. Chorographia histórica da Província de Goyas. In. Revista do Instituto Histórico, Geográfico e Etnographico do Brasil. Rio de Janeiro: R. I. Garnier, Tomo XXXVIII (1), p. 6-150, 1875.

MATTOS, José Raymundo da Cunha. Itinerár

io do Rio de Janeiro ao Pará e Maranhão pelas Províncias de Minas Gerais e Goyaz, seguido de huma descripção chorographica de Goiaz, e dos roteiros desta província as de Mato Grosso e São Paulo. Rio de Janeiro: Typographia Imperial e Constitucional de J. Vilaleneuve E. C., Tomos I e II, 1836.

MATTOS, R. J; BARBOSA, J. C. Discurso. In. Revista do Instituto Histórico e Geográfico do Brazil. I. Rio de Janeiro: Imprensa nacional, $3 .^{\circ}$ ed, $1 .^{\circ}$ Trimestre, Tomo I, N. 1, p. 6-8, 1908. 
MATTOS, José Raymundo da Cunha. Dissertação acerca do sistema de escrever a história antiga e moderna do Império do Brasil. In. Revista do Instituto Histórico, Geográfico e Etnográfico do Brasil. Rio de Janeiro: Tipografia de D. Luiz dos Santos, tomo XXVI, Vol. 150, p.121-143, 1863.

NUNES, T. T. Liberdade de imprensa no Império Brasileiro: debates parlamentares (1820-1840) p. 65-66. Dissertação (Mestrado em História), FFLCH/USP, São Paulo, 2010.

RODRIGUES, N. B. Nos caminhos do Império: a trajetória de Raimundo José da Cunha Mattos. 2008 p. 219-220. Tese (Doutorado em História), Instituto de Ciências Humanas, UnB, Brasília, 2008. Disponível em: <http://repositorio.bce.unb.br/bitstream/10482/5134/1/2008_NeumaBRodrigues.pdf $>$. Acesso em: 20 ago. 2015 p. 210.

SERRÃO, Joel (Dir.). Decadência. In. Dicionário da história de Portugal. Porto: Livraria Figueiredo, vol II, 1981. p. 270-271.

SOARES, Gerusa. Cunha Mattos (1776-1839): fundador do Instituto Histórico, Geográfico Brasileiro. Rio de Janeiro: Empresa Gráfica e Editora, 1931 p. 15.

TURIN, Rodrigo. A “obscura história” indígena: o discurso etnográfico no IHGB. In. GUIMARÃES, Manoel Luiz Salgado (Org.). Estudos sobre a escrita da história. Rio de Janeiro: 7Letras, 2006. p. 86-113.

VIEIRA, Martha Victor. Cunha Mattos em Goiás: os conflitos de jurisdição entre o Governo das Armas e o Governo Civil (1823-1826). In. Revista Territórios e Fronteiras. Programa de Pós-Graduação da UFMT, vol. 5, n. 2. p. 224-242, jul/dez.2012.

Recebido: $29 / 08 / 2018$

Aceito: $21 / 02 / 2019$

Publicado: 13/05/2019

\footnotetext{
' Doutora em História Social pelo Instituto de Filosofia e Ciências Sociais da Universidade Federal do Rio de Janeiro. Professora adjunto III do Colegiado de História da Universidade Federal do Tocantins (UFT), campus de Araguaína. Atua também no Programa de Mestrado Profissional em Ensino de História (ProfHistória) e no Programa de Pós-Graduação em Estudos de Cultura e Território na UFT. E-mail: martha.victor@uft.edu.br
} 